\title{
特集 認知症とリハビリテーション医学
}

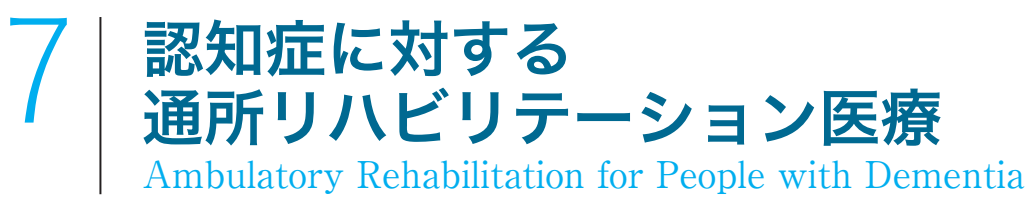

高尾芳樹*

Yoshiki Takao

Key words : 通所リハビリテーション医療／認知症／居宅／地域連携／多重課題

通所リハビリテーション医療は，介護保険制度の居宅給付として提供されている。認知症患 者が急速に増加する中で, 多職種協働の専門チームにより利用者個々の状態に合わせさまざ まな介入技法を組み合わせた認知症に対するリハビリテーション医療が提供され, 認知機能 改善, 行動・心理症状軽減などの効果が示されている. 居宅に潜在する要支援・要介護受給 者の通所をいかにして促すかは大きな課題となっているが, 魅力的な楽しめるプログラムの 提供などにより通所促進が図られ，地域包括ケアシステム構築が促進される中で，通所リ八 ビリテーション医療の役割は重要である.

\section{はじめに}

通所リハビリテーション医療は, 2000 年度の介 護保険制度開始に伴い, 高齢者の心身機能維持 · 改善を図る国の施策として制度化され，要支援 1〜要介護 5 の受給者を対象にした居宅給付とし て提供される. 専属医師 1 名と, 理学療法士 (physical therapist : PT), 作業療法士 (occupational therapist : OT), 言語聴覚士 (speech language hearing therapist：ST）から利用者 10 名あ たり 1 名の設置が義務づけられ，専門的なリハビ リテーション医療を提供する。 2006 年度の介護保 険改正で, 要支援 $1 \cdot 2$ の受給者を対象に予防に重 点を置く介護予防通所リハビリテーション医療が 開始され, 要介護 1 5 の給付者には身体機能や生 活機能の維持・改善を目標にした新たな通所リハ

* 社会医療法人全仁会倉敷平成病院脳神経内科

（ ₹710-0826 岡山県倉敷市老松町 4-3-38）

E-mail : y4ktakao@heisei.or.jp

DOI : 10.2490/jjrmc.55.664
ビリテーション医療が提供されている1). 本稿で は, 介護予防通所リハビリテーション医療と通所リ ハビリテーション医療を合わせて通所リハビリテー ション医療とする.

認知症治療では, 非薬物療法が重要な役割を 担っており，その中核は認知症に対するリハビリ テーション医療（認知症リハビリテーション医療） である ${ }^{2)}$. 認知症患者では, ちょっとした環境変化 で認知機能の低下や行動・心理症状（behavioral and psychological symptoms of dementia : BPSD) の悪化を誘発しやすく, 国は認知症患者も地域で 支える地域包括ケアシステムの構築をめざしてお り, 利用者が慣れた居宅環境を維持しつつ認知症 リハビリテーション医療を提供できる通所リハビリ テーション医療の果たす役割は大きい. 本稿では, 全仁会での取り組みを紹介しながら, 通所リハビリ テーション医療における認知症リハビリテーション 医療の現状と効果, 課題について述べる. 
全仁会の通所リハビリテー ション医療における認知症リ ハビリテーション医療の取り 組みと主な介入技法

全仁会は, 岡山県認知症疾患医療センターに認 可された倉敷平成病院 220 床と老人保健施設（老 健）の倉敷老健 150 床を中核とした社会医療法人, 倉敷在宅総合ケアセンター, 複合型介護施設, 軽 費老人ホームなどを展開する社会福祉法人から構 成され, 開設当初より救急から在宅までの一貫し た医療・リハビリテーション医療・ケアの提供をめ ざしている，病院が事業主体の介護予防リハビリ テーション医療と倉敷老健が事業主体の通所リハ ビリテーション医療を提供しており, 医師, PT, OT, ST, 臨床心理士 (clinical psychologist: CP), 看護師, 介護福祉士からなる多職種の認知症専門 チームがパーソンセンタードケアの理念に基づき, 利用者個々の病状, ニーズ, 生活環境などを考慮 乙運動療法, 認知機能訓練, 認知刺激, reality orientation $(\mathrm{RO})$, 認知リハビリテーション, 音楽 療法, 回想法, 認知行動療法などの介入技法の中 から利用者に最適な技法を選択し, 集団 - 個別療 法の組み合わせと提供施設を決定して認知症リハ ビリテーション医療を実施している. 囲碁などの 知的要素や, スポーツなどの身体的要素, ボラン ティア活動などの社会的要素から好みに合わせて 選択した余暇活動も併せて行っている.

\section{1. 身体運動}

認知症の予防や認知機能改善に有効性が示され ている介入技法としては, まず身体運動が挙げら れる. アルツハイマー型認知症 (AD) の認知機能 改善, 軽度認知障害での言語流暢性の改善, 認知 症のない高齢者での注意や判断力の改善が報告さ れている2,3).
近年, 複数の課題を組み合わせた多重課題の介 入技法が注目されている. 国立長寿医療研究セン ターの Suzuki ら ${ }^{4)}$ は身体運動に認知課題を組み合 わせたコグニサイズを提唱し, 軽度認知障害を呈 する日本人高齡者を対象とした randomized controlled trial (RCT) において, 論理的記憶と mini mental state examination (MMSE) 得点の改善や 海馬萎縮進行の抑制を報告している.

大藏ら ${ }^{5)}$ が開発した Square-Stepping Exercise (SSE) も多重課題の 1 つで, $25 \mathrm{~cm}$ 四方の升目（ス クエア）で区切った専用のマット上を指定されたパ ターンに従ってステップを踏むエクササイズであ る. 特徴として, 段階的に難易度（動きの複雑さ） が増すことから参加者の挑戦意欲をかきたてるだ けでなく, 注意力, 集中力, 記憶力を駆使しなけれ ば遂行困難な設計になっている ${ }^{5,6)}$. 施術者が専 門講習を受ける必要はあるが, 必要物品は専用マッ トと指示板くらいで安価に導入できる. 大藏ら ${ }^{5)}$ は 自立高齢者への介入で, 認知機能の改善と身体機 能の向上を同時にもたらす可能性を示唆し, 初期 の認知症患者に対しても同様の効果が期待されて いる. 全仁会の通所リハビリテーション医療でも 身体機能向上と転倒予防効果を示している7). 今 回, 少数例ではあるが, 認知機能への効果を検討 したので紹介する。

2015 年 6 9 月の通所リハビリテーション医療 利用者で参加の同意を得られた 24 名を準無作為 にSSE 介入群 18 名と対照群 6 名に割り付け, SSE 介入群は, 従来のプログラムに週 1 回の SSE を交えたトレーニングを 90 分間・全 12 回を追加 実施し, 対照群はSSE の代わりにストレッチなど のリラクゼーションを同様に実施し, 介入前後で効 果を評価した. 年歯, 性別, 介護度, 既往歴, 認知 機能などの利用者背景は 2 群間に差はなく, 介入 前後の評価は, five cognitive functions test (5cog) の 5 つの知的機能課題「記憶」,「注意」, 「言語機 


\begin{tabular}{lccc}
\hline \multicolumn{1}{c}{ SSE 群 18 名 } & $\begin{array}{c}\text { 介入前 } \\
(\mathrm{m} \pm \mathrm{SD})\end{array}$ & $\begin{array}{c}\text { 介入後 } \\
(\mathrm{m} \pm \mathrm{SD})\end{array}$ & $\mathrm{p}$ \\
\hline 手の運動 & $15.3 \pm 6.6$ & $18.3 \pm 4.7^{*}$ & 0.03 \\
\hline 注意 & $13.7 \pm 8.6$ & $15.2 \pm 9.0^{*}$ & 0.02 \\
\hline 言語機能 & $13.1 \pm 4.3$ & $13.5 \pm 5.0$ & 0.58 \\
\hline 記憶 & $13.2 \pm 5.9$ & $14.4 \pm 6.1$ & 0.16 \\
\hline 視空間認知 & $6.1 \pm 1.5$ & $6.4 \pm 1.1$ & 0.24 \\
\hline 思考 & $10.1 \pm 3.9$ & $10.5 \pm 3.8$ & 0.39 \\
\hline リラクゼーション群 & $\begin{array}{c}\text { 介入前 } \\
(\mathrm{m} \pm \mathrm{SD})\end{array}$ & $\begin{array}{c}\text { 介入後 } \\
(\mathrm{m} \pm \mathrm{SD})\end{array}$ & $\mathrm{p}$ \\
\hline 手の運動 & $11.7 \pm 6.7$ & $14.6 \pm 5.6$ & 0.10 \\
\hline 注意 & $7.9 \pm 7.5$ & $11.4 \pm 9.3$ & 0.78 \\
\hline 言語機能 & $11.7 \pm 3.1$ & $10.0 \pm 3.4 *$ & 0.03 \\
\hline 記憶 & $11.9 \pm 5.8$ & $13.0 \pm 5.8$ & 0.82 \\
\hline 視空間認知 & $5.9 \pm 2.4$ & $5.1 \pm 2.5$ & 0.18 \\
\hline 思考 & $9.3 \pm 2.6$ & $7.4 \pm 4.3$ & 0.20 \\
\hline
\end{tabular}

\section{表 1 SSE の認知機能への効果（50og による検} 討)

SSE 群 18 例とリラクゼーション群 6 例で, $5 \operatorname{cog}$ の 5 つ の知的機能課題「記憶」,「注意」,「言語機能」、「視空間認 知」,「思考」と運動課題の「手の運動」を行い, 6 つの課 題について介入前後の評価結果を比較した。「手の運動」 と「注意」の課題では, SSE 群は介入前後で有意に改善 し, リラクゼーション群は有意な変化を認めなかった. 「言語機能」の課題では, SSE 群は介入前後で維持され ていたが, リラクゼーション群は介入前後で有意に低下 していた。「視空間認知」と「思考の課題」では, SSE 群 もリラクゼーション群も有意な変化は認めなかった。 Data は平均 (mean : m) 土標準偏差 (standard deviation : SD) で表示し, 統計解析は Statistical Package for Social Science (SPSS) statistics version 17.0 を用 い, 正規性を確認後, t 検定, Wilcoxon 検定, MannWhitney 検定を用いて検討し, 有意水準 ( $p$ value : $p$ ) は $5 \%$ 末満 $(* p<0.05)$ とした.

能」,「視空間認知」,「思考」と運動課題の「手の運 動」で行った. SSEは, 通所リハビリテーション 医療利用者の身体機能改善だけでなく認知機能の 維持・改善効果が期待できる介入技法であること が示唆された（表 1)。

\section{2. 音楽療法}

全仁会では「思い切り歌って心も体も健康に」を 謳い文句に音楽療法士らのピアノ生伴奏による音 楽療法を通所リハビリテーション医療に取り入れ ており, 複合型の音楽療法として週に 1 回の歌声 広場を開催している。歌声広場は 2018 年 5 月 23 日に第 1,500 回を迎え, 約 150 名が参加している. なじみの深い童謡や唱歌, 昭和歌謡などの懐かし のメロディーを 5〜6曲, スタッフによる生バンド 演奏とリードに合わせて合唱する．歌唱しながら リズムに合わせて手拍子をとりステップを踏むなど の多重課題的側面もあれば，歌唱の合間にスタッ フや利用者が小グループをつくり歌唱曲に関連し た昔の話題や利用者自身の経験・経歴を披露しあ うなど集団型 RO の側面もみられる22.

\section{3. 認知症短期集中リハビリテーション 医療}

2006 年度の介護保険改定でリハビリテーション 医療のあり方が見直され, 認知症短期集中リハビ リテーション医療が導入された1)。精神科医師も しくは神経内科医師または認知症に対するリハビ リテーション医療の研修を受けた医師の指示のも と, 対象者に $\mathrm{PT} \cdot \mathrm{OT} \cdot \mathrm{ST}$ が, 週 3 回, 1 回 20 分 以上の個別リハビリテーション医療を 3 力月以内 の短期間に集中して実施する。当初は老健入所者 で軽度〜中等度認知症に限定されたが，2009 年度 の介護保険改定に伴い通所リハビリテーション医 療利用者も対象となり, 重度認知症へも対象範囲 が拡大し改訂長谷川式簡易知能評価スケール (Hasegawa's dementia scale-revised : HDS-R) や MMSE が 5 25 点の範囲で実施可能となっ $た^{1,8)}$.

\section{通所リハビリテーション医療 の効果}

個々の介入技法の効果は, RCT や meta analysisでも有効性が報告されており，近年，通所リハ 
ビリテーション医療でも有効性を示す報告がみら れるようになった。

全国老人保健施設協会は，2012 年度に通所リハ ビリテーション医療における認知症短期集中リハ ビリテーション医療の効果を検証する調查研究事 業を行っている. 20 施設が協力し, 介入群 52 名 と対照群 41 名を検討し, 認知機能面だけでなく, BPSD や日常生活動作の改善効果を報告してい $ろ^{8)}$.

Yamaguchi $ら^{9)}$ は, 認知症リハビリテーション 医療に際して, RO や回想法などの介入技法の選 択よりも，かかわる施設スタッフの認知症患者への 受容や接し方などの介入の方法論を統一して認知 症リハビリテーション医療に取り組むことの重要 性を示し, 介入の方法論を快・会話・役割・褒め る・成功体験の 5 項目にまとめ「脳活性化リハビリ テーション医療 5 原則 (脳リハ 5 原則)」として提 唱し, 老健入所者 122 名に「脳リハ 5 原則」に則っ て介入し, 認知症短期集中リハビリテーション医 療が，認知機能と意欲を向上させ BPSD と抑うつ 症状を軽減することを報告している ${ }^{10)}$ 。全仁会の 通所リハビリテーション医療でも「脳リハ 5 原則」 を取り入れ認知症リハビリテーション医療に取り 組んでいる. 岡山大学脳神経内科との共同研究に おいて, 抗認知症薬と通所リハビリテーション医 療の併用というかたちだが, 通所リハビリテーショ ン医療に拈ける認知症リハビリテーション医療の 有効性を報告している。通所リハビリテーション 医療利用者でドネペジル服用中の $\mathrm{AD}$ 患者 55 名 を対象にした 1 年間の観察研究では, ドネペジル 服用のみの群（23 名）では MMSE は維持程度で あったが，認知症リハビリテーション医療を併用 した群 (32名) の MMSE は $21.7 \pm 2.2$ から $24.6 \pm 1.6$ 人有意に改善した（平均士標準偏差，有 意水準 $; \mathrm{p}<0.05)^{11)}$ 。また, 全仁会の利用者に岡 山大学病院脳神経内科関連施設の利用者を加えた
ガランタミン服用中の $\mathrm{AD}$ 患者 86 名を対象とした 6 カ月の観察研究では, ガランタミン服用のみの群 （45名）に対して認知症リハビリテーション医療 を追加した群（41名）では，6力月目の MMSEと frontal assessment battery（FAB）, 3 カ月目と 6 カ月目の apathy scale (AS) が有意に改善してい た ${ }^{12)}$ 。通所リハビリテーション医療における認知 症リハビリテーション医療は, 認知症の諸症状に 対しての改善効果があり, 抗認知症薬との併用で より効果が得られると思われた。

\section{通所リハビリテーション医療 の課題}

1。通所リハビリテーション医療への 参加促進, 楽しんでできる リハビリテーション医療の実現

居宅の要支援・要介護認定者で通所リハビリ テーション医療未利用者に対していかにして通所 を促すかは，以前から継続する課題である．利用 者は明らかに男性が少なく, 男性の利用促進も課 題である. 提供施設では，アメニティーの工夫を し, 賛否はあるがギャンブル性のある遊戯ゲームや 本格的な運動器具によるフィットネスを取り入れ て興味を引き楽しんでできるリハビリテーション 医療の提供に腐心している. Yamaguchi $ら^{9)}$ は, 利用者が楽しんでできるリハビリテーション医療 が認知症予防や進行抑制に特に有用であると指摘 している.

全仁会では利用者・家族へのアンケートや利用 者の表情を visual analogue scale 化して楽しんで できているかの評価を行い，個々の介入技法を修 正している。 しかし，利用者の気分を十分評価で きているかは不明で，客観的に利用者の気分を評 価できれば, 認知症リハビリテーション医療の効 果の向上が期待される. 
2. 地域包括ケアシステムにおける 通所リハビリテーション医療の役割

地域包括ケアシステムが促進される中で, 通所 リハビリテーション医療は, ケア主体の通所介護, 特に認知症対応型通所介護との明確な役割分担 や，本来あるべき姿である短時間のリハビリテー ション医療への移行, 自立支援・重度化予防のた めリハビリテーション機能強化が求められてい $る^{13)}$. 2018 年度の介護報酬改定では短時間型通 所リハビリテーション医療に手厚い診療報酬と なっており ${ }^{14)}$ ，その流れを受けてリハビリテーショ ン医療に特化した短時間型通所リハビリテーショ ン医療を提供する事業所も増加傾向にある。一 方, さまざまな介護保険サービスや医療機関, 施設, 居宅事業所間の連携強化も今後の課題である ${ }^{13)}$.

\section{おわりに}

全仁会での取り組みを紹介しながら，認知症に 対する通所リハビリテーション医療の現状と効 果, 問題点について概略を述べた，通所リハビリ テーション医療では利用者の認知症予防, 認知機 能や BPSD の改善に積極的に取り組んでおり, 一 定の有効性が示されている. 地域包括ケアシステ ム構築が促進される中, 居宅で認知症リハビリテー ション医療を提供する通所リハビリテーション医 療は重要性を増しており, 提供するリハビリテー ション医療のさらなる強化や地域の各施設間の連 携促進が求められている.

\section{文 献}

1）厚生労働省老健局：高齢者の地域におけるリハビリ テーションの新たな在り方検討会報告書 平成 27 年 4 月 13 日公開. 2015. Available from URL; http:// www.mhlw.go.jp/stf/shingi2/0000081906.html

2）日本神経学会 監,「認知症疾患診療ガイドライン」作 成委員会 編: 認知症疾患診療ガイドライン 2017. 医 学書院, 東京, 2017; pp 67-91, 133-136, 161-162, 230-236
3) 村田 伸, 大杉絋徳：認知症者に対する運動療法の 効果一文献レビューを中心に。理学療法 2016；33： 43-51

4) Suzuki T, Shimada H, Makizako H, Doi T, Yoshida D, Ito K, Shimokata H, Washimi Y, Endo H, Kato T : A randomized controlled trial of multicomponent exercise in older adults with mild cognitive impairment. PLoS One $2013 ; 8$ : c61483

5）大藏倫博, Yoon Ji-Yeong, 真田育依, 村木敏明, 重 松良祐, 中垣内真樹: 新転倒・認知症予防プログラム が地域在住高齢者の認知・身体機能に及ぼす影響— 脳機能賦活を意図した「スクエアステップ」エクササ イズの検討. 日本認知症ケア学会誌 $2010 ; 9$ : 519-530

6) Shigematsu $R: A$ novel exercise for improving lower-extremity functional fitness in the elderly. Aging Clin Exp Res 2006 ; 18 : 242-248

7) 高尾芳樹：認知症リハビリの最前線. 日本内科学会 雑誌 $2014 ； 103 ： 1839-1846$

8）全国老人保健施設協会：平成 24 年度 老人保健健 康増進等事業. 通所リハビリテーションにおける認 知症短期集中リハビリテーションの有用性に関する 調査研究事業 報告書, 平成 25 年 3 月, 2013. Available from URL : http://www.roken.or.jp/wp-wpco ntent/uploads/2013/04/efd62ad6790c6887ab83d5c6 ec3f5f8 d.pdf

9) Yamaguchi H, Maki Y, Yamagami T : Overview of non-pharmacological intervention for dementia and principles of brain-activating rehabilitation. Psychogeriatrics $2010 ; 10: 206-213$

10）関根麻子, 永塩杏奈, 高橋久美子, 加藤 實, 高玉 真光, 山口晴保 : 老健における認知症短期集中リハ ビリテーション：脳活性化リハビリテーション 5 原則 に基づく介入効果. Dementia Japan 2013;27: 360-366

11) Matsuzono K, Hishikawa N, Takao Y, Wakutani Y, Yamashita T, Deguchi K, Abe K : Combination benefits of cognitive rehabilitation plus donepezil for Alzheimer's disease patients. Geriatr Gerontol Int $2016 ; \mathbf{1 6}: 200-204$

12) Tokuchi R, Hishikawa N, Matsuzono K, Takao Y, Wakutani Y, Sato K, Kono S, Ohta Y, Deguchi K, Yamashita T, Abe $\mathrm{K}$ : Cognitive and affective benefits of combination therapy with galantamine plus cognitive rehabilitation for Alzheimer's disease. Geriatr Gerontol Int 2016； 16 : 440-445

13）厚生労働省：平成 30 年度介護報酬改定における各 サービス毎の改定事項について. 第 158 回社会保障 審議会介護給付費分科会 参考資料 1，2018. Available from URL : http://www.mhlw.go.jp/stf/shingi 2/0000192309.html

14）厚生労働省：平成 30 年度介護報酬改定の主な事項 について．第 158 回社会保障審議会介護給付費分科 会資料 1. 2018. Available from URL : http://ww w.mhlw.go.jp/stf/shingi2/0000192309.html 